\title{
PONDOK PESANTREN DAN RADIKALISME AGAMA \\ (Studi Pada PPM. TMI Al Istiqamah \\ Kabupaten Donggala)
}

\author{
Oleh: Abd. Kadir R
}

\begin{abstract}
Abstrak
This research was conducted in Donggala, Middle Sulawesi. The focus research is Pesantren TMI Al-Istiqomah. This research aims to describe how radicalism potency in this Pesantren. This use quantitative and qualitative method, where data was collected by using questioner to a number students and interview to the teachers. The data was analyzed by descriptive analysis..

This research indicates that there are some indicators posed at Pesantren potency don't embrace radicalism understanding, such as: attitude frown upon hardness by bomb suicide action, even though with reason of jihad. They also confess and respect the existence of other religion followers.
\end{abstract}

Key words: Pesantren Al-Istioqomah, radicalism, religion.

\section{PENDAHULUAN}

alah satu kajian menarik pasca stragedi 12 Oktober 2002 (Bom Bali) adalah bagaimana menjelaskan aksi radikalisme dan terorisme di

Indonesia. Hampir semua Negara yang memiliki kelompok Islam keras berupaya sekuat tenaga untuk menyumbangkan berbagai pandangan untuk menyatakan bahwa umat itu bukan teroris, dan tidak semua aksi teroris mewakili umat Islam. Dalam konteks inilah, upaya para Sarjana Islam untuk menjelaskan Islam kepada Barat menjadi sangat berat. Tantangan yang dihadapi ibarat dua mata koin. Satu sisi, terdapat nilai-nilai dalam Islam yang tampaknya sama sekali jauh dari terorisme dan wajib bagi umat Islam untukmengatakan kepada dunia 
terdapat nilai-nilai dalam Islam yang tampaknya sama sekali jauh dari terorisme dan wajib bagi umat Islam untuk mengatakan kepada dunia bahwa mereka bukan teroris. Sisi lain, Barat melalui aksi propagandanya telah berhasil menciptakan image bahwa ada sekelompok umat Islam yang harus dicurigai karena mereka disinyalir melakukan aksi terorisme.

Radikalisme agama yang kemudian berimplikasi pada lahirnya terorisme kemudian dicurigai realisasi dari penafsiran keagamaan yang fundamental dan radikal. Kecurigaan yang mengglobal ini kemudian menjadikan lembaga keagamaan tersudutkan. Kelompok Islam yang dianggap kanan dengan ciri-ciri tertentu mendapatkan stigma negative dari masyarakat karena dianggap sebagai biang keladi kerusuhan dan terorisme bom. Fakta bahwa, beberapa pelaku bom adalah alumni pesantren (setidaknya ada beberapa pesantren yang sering disebut sebagai tempat reproduksi para teroris, salah satu diantaranya Pesantren Ngaruki Surakarta) seolah menjadi pembenaran, bahwa betapa selama ini lembaga pendidikan keagamaan, khususnya pesantren telah menjadi pembasisan bagi generasi yang siap melakukan teror.

Berdasarkan latar belakang masalah di atas, maka pertanyaan penelitian yang muncul adalah adakah potensi radikalisme yang berkembang di Pondok Pesantren Al Istiqamah ? Sedangkan tujuan penelitian ini adalah untuk mendeskripsikan potensi radikalisme di Pondok Pesantren Al Istiqamah. Hasil yang diharapkan dari penelitian adalah terciptanya kebijakan pemerintah mengenai pengawasan terhadap gerakangerakan radikal yang mengancam solidaritas sosial.

\section{KERANGKA TEORI}

Radikalisme berasal dari kata radix yang berarti akar. Kata radikal pada mulanya merupakan kata yang popular dikalangan filsuf dengan berpikir radikal, berarti berfikir secara detil hingga ke akar-akarnya. Perkembangan selanjutnya menunjukkan bahwa, konsep radikalisme tidak lagi difahami dari sudut pandang intelektualisme. Konsep ini bergeser ke wilayah gerakan sosial keagamaan. Radikalisme dalam konteks gerakan berarti suatu gerakan yang menggunakan kekerasan sebagai cara yang utama. Gerakan radikal tidak lagi menempuh cara-cara negosiasi, tawar menawar sebagai alternatif pencapaian tujuan, tetapi dengan kekerasan. Gerakan radikal tidak hanya berasal dari komunitas agama saja, tetapi jugaberasal dari ideologi tertentu seperti gerakan radikal 
kiri Che Guevara dan Zapatista yang merupakan refleksi dari pemikiran kritis Karl Marx.

\section{Pendekatan Fungsionalisme}

Akar fungsionalisme dapat ditemukan dalam karya Durkheim yang memiliki jejak sangat berarti dalam pemikiran sosiologi dan antropo'logi kontemporer. Dua prinsip Durkheim yang paling utama adalah: 1) kekuatan-kekuatan sosial memberikan paksaan eksternal pada individu-individu, dan 2) individu-individu ini sendiri terorganisir secara hirarkis oleh kekuatan-kekuatan tersebut (Troung, 1992:35).

Malinowski dan R Brown merupakan dua antropolog yang merupakan pelanjut aliran fungsional. Malinowski tertarikpadakebutuhan-kebutuhanpsikologis dan biologis, dan fungsi-fungsi yang harus dipenuhi agar masyarakat berkembang. Sedangkan Brown tertarik padakebutuhan-kebutuhan sosiologis dan fungsi-fungsi institusi dalam sistem sosial.

Pendekatan fungsional menekankan pada kekuatan institusional sebagai instrumen yang paling penting dalam menentukan arah kebudayaan. Menurut Berger (dalam Wuthnow, 1987:41), bahwa institusi tidak hanya mengatur, membuatregulasi, tetapi juga melakukan kontrol terhadapperilaku masyarakatnya.

Berangkat dari prinsip fungsionalisme Durkheim, lembaga pendidikan sebagai salah satu institusi sosial memberikan paksaan eksternal kepada anak didiknya untuk ikut dalam apa yang telah dikonstruksi oleh pendidik. Anak didik secara otomatis diproyeksikan untuk masuk dalam lingkaran paedagogik yang telah diatur sedemikian rupa oleh sistem pembelajaran di sekolah. Dengan demikian, perilaku sosial masyarakat sangat ditentukan nilai-nilai dominan yang dibangun dalam institusi sosial termasuk lembaga pendidikan.

\section{METODE PENELITIAN}

Penelitian ini dilaksanakan di Provinsi Sulawesi tengah, tepatnya Desa Ngata Baru Kecamatan Sigi Biromaru, Kabupaten Donggala.Desa ini merupakan daerah Pondok Pesantren Moderen Tarbiyatul Muallimin al-Islamiy ah (PPM-TMI) Al Istiqamah berada.

Pengumpulan data dilakukan dengan dua cara, yaitu penyebaran angket kepada 
50 orang santri dan wawancara dilakukan kepadapimpinan pondok pesantren dan guru-guru pondok.

Pengolahan dan analisis data dilakukan dengan menelaah seluruh data yang tersedia dari berbagai sumber,kemudian direduksi dan selanjutnyamenyusun kedalam satuansatuan, lalu dikategorisasi. Sedangkan data yang diperoleh melalui angket dianalisis dengan pendekatan deskriptif-kualitatif.

\section{TEMUAN DAN PEMBAHASAN}

\section{A. Profil Pesantren Al Istiqamah.}

\section{Sejarah Dan Latar Belakang Berdirinya}

Pondok Pesantren Modern Tarbiyatul Muallimin Al Islamiyah (PPM-TMI Al Istiqamah) didirikan pada tanggal 2 Mei 1993 oleh K.HM.Arif Siraj, L.C. dan sekaligus menjadi pimpinan pondok. K.H.M.Arif Siraj lahir di Desa Ougamas Kabupaten Donggala, walaupun dlahirkan di tanah Kaili, namun diaberdarah Bugis asli, karena kedua orang tuanya berasal dari tanah Bugis. Ibunya berasal dari Kabupaten Barru, dan ay ahny a berasal dari Kabupaten Sinjai Provinsi Sulawesi Selatan.

Sebelum mendirikan pondok Pesantren Al Istiqamah,Arif Siraj,menjadi salah seorang tenaga pengajar di Madrasah Aliyah Negeri 1 Kota Palu. Tidak lama menjadi tenaga pengajar di Madrasah Aliyah, dia dipindahtugaskan menjadi pimpinan salah satu pesantren yakni Pondok Pesantren Nurul Falah yang dibina oleh Organisasi Muhammadiyah Wilayah Sulawesi Tengah. Perpindahan ini atas permintaan Drs.Muhammad Na'im yang pada waktu itu menjabat sebagai Kepala Kantor Wilayah Departemen Agama Provinsi Sulawesi Tengah, dan sekaligus menjadi penasihat di pesantren tersebut. Permintaan yang sama datang dari Prof.H.Ishak Arief,yang menjadi ketua Yayasan Pondok Pesantren Nurul Falah.

Setelah memimpin Pesantren Nurul Falah selama tiga tahun, karena terdapat beberapa prinsip yang berbeda dengan pimpinan dan pengurus lainnya, sehingga dia mengundurkan diri dari pesantren tersebut, kemudian karena jiwa kesantrian yang begitu kental dia mendirikan sebuah pesantren yang dipimpinnya sekarang. 
Pendirian pondok pesantren Al Istiqamah dilatari oleh suatu tekad untuk me wuj udkan program dari PPM-KMI Darussalam Gontor yaitu Program Seribu Gontor. Program tersebut dicanangkan dengan tujuan untuk penegakan kalimat Allah dimanapun para alumni Gontor berada. Dan K.H.M Arif Siraj merupakan salahseorang alumni Gontor.

Pada awal pembangunan dilengkapi dengan lima buah bangunan yang sangat sederhana yang berlantai tanah, berdinding papan, dan atap dari daun rumbia. Kelima bangunan tersebut difungsikan sebagai ruang belajar, pemondokan santri, ruang makan, perumahan ustaz/pengasuh termasuk rumah Arif Siraj.

\section{Sarana dan Prasarana}

Pada awal pembangunan Pesantren Al Istiqamah, diawali dengan beberapa sarana yang sangat sederhana, maka tahun selanjutnya atas kerja keras dari pengurus berhasil mengembangkan dan menambah beberapa sarana dan merenovasi beberapa sarana sebelumnya yang sangat sederhana. Pengadaan beberapa sarana tersebut merupakan hasil swadaya Pembina dan orang tua santri, ditambah dari beberapa dermawan, dan dari Departemen Agama.

Adapun beberapa sarana yang telah berhasil dikembangkan diantaranya: lokasi pesantren yang pada awal pembangunannya seluas 3 ha, kemudian menjadi 7 ha. Kemudian sarana lainnya yang telah dimiliki berupa bangunan dan sarana lainnya telah mencapai 38 buah terdiri atas, gedung kelas DarulFikri; pos penjagaan; kantor administrasi; rumah pimpinan pondok; koperasi pelajarputri; gedung kelas Darussalam; asrama putri; koperasi pelajar putra; asrama pengasuh/ustaz; asrama santri; aula gedung pertemuan; gedung ketrampilan; gedung perpustakaan; kafe putra; gedung laboratorium [PA; lapangan basket; mesjid; UKS/musala untuk putri; asrama putri/ustazah; gedung kelas; laboratorium komputer/kelas Darul Ulum; kamarmandi putri, kafe putri; kamar mandi putra; perumahan guru/ustaz; gedung/ruang makan putra dan putri, dapur, bak air; tempat wudhu, dan etalase Koran.

Khusus gedung Darul Fikri sampai saat ini masih dipertahankan keasliannya seperti pada saat awal pembangunannya, yakni masih berlantai tanah, berdinding papan, beratap dari daun rumbia. Menurut salah seorang pembina keadaan ini sengaja 
dipertahankan untuk mengenang bagaimana awal mula perjuangan mendirikan pesantren ini.

\section{Tenaga Pengajar/Pengasuh}

Pondok Pesantren Moderen Tarbiyatul Muallimin Al Islami (PPM-TPM"A1 Istiqamah) dalam melakukan kegiatan proses belajar mengajar dilakukan oleh tenaga pengajar sebanyak 42 orang, terdiri atas laki-laki sebanyak 32 orang,dan perempuan sebanyak 10 orang. Tenaga pengajar tersebut berasal dari berbagai daerah, seperti dari Provinsi Sulawesi Tengah, Sulawesi Barat, dan Gorontalo. Bahkan ada beberapa diantarany a berasal dari luar Pulau Sulawesi seperti, dari Pulau Sumatra, Pulau Jawa, dan Papua.

Kemudian dari tingkat pendidikan, sebahagian besar diantaranya yakni sebanyak 23 orang $(71,87 \%)$ berijazah sarjana (S1), satu orang berijazah diploma dua (D2) dan selebihnya atau 22 orang berijazah setingkat SLTA, namun beberapa diantaranya sedang menuntut ilmu di perguruan tinggi yang ada Kota Palu.

Selain tingkat pendidikan yang beragam, mereka juga berasal dari latarbelakang pendidikan yang beragam diantaranya: Pendidikan Agama Islam (56,7 \%); Sarajana Bahasa Arab (21,7 \%); IPS/Akuntansi (8,6 \%); Dakwah dan Matematika, masingmasing $4,3 \%$.

\section{Keadaan santri}

Jumlah santri pada tahun ajaran 2005/2006 sebanyak 457 orang yang terbagi kepada enam kelas atau rombongan belajar. Kelas satu sampai kelas tiga adalah tingkat tsanawiyah, sedangkan kelas empat sampai kelas enam adalah tingkat Aliyah.

Dari jumlah santri yang ada, yang paling banyak terdapat kelas satu dengan jumlah santri sebanyak 158 orang, disusul kelas dua dengan jumlah santri sebanyak 120 orang. Dan kelas yang paling sedikit jumlah santri adalah kelas empat dengan jumlah santri sebanyak 29 orang. Untuk jelasnya dapat dilihat pada tabel berikut.

Jumlah Santri/santriwati PPM-TMI Al-Istiqamah Menurut Kelas Tahun Ajaran 2005/2006. 


\begin{tabular}{|c|c|c|c|}
\hline No & Tingkatan Kelas & F & \% \\
\hline 1 & I & 158 & 34,57 \\
\hline 2 & II & 120 & 26,25 \\
\hline 3 & III & 80 & 17,50 \\
\hline 4 & IV & 29 & 6,34 \\
\hline 5 & V & 30 & 6,56 \\
\hline 6 & VI & 40 & 8,75 \\
\hline
\end{tabular}

Sumber: PM-TMI Al Istiqamah.

Meskipun pesantren ini termasukbaru (dibuka tahun 1993) yang lalu, namun sudah mendapat respon positif dari masyarakat dengan memasukkan anaknya belajar di pesantren ini. Hal ini ditandai denganperkembangan jumlah santri dari tahun ke tahun, setidaknya jika dilihat keadaan tiga tahun ajaran terakhir mulai tahun ajaran 2003/2004 jumlah santri sebanyak 414; tahun ajaran 2004/2005jumlah santri sebanyak 445 orang, dan pada tahun ajaran 2005/2006 meningkat lagi menjadi 457 orang.

Mengenai asal daerah sebahagian besar diantarany a berasal dari beberapa kabupaten yang ada di Provinsi Sulawesi Tengah. Selain itu ada beberapa diantaranya berasal dari luar Provinsi Sulawesi Tengah, seperti Mamuju (Sulawesi Barat), Makassar (SulawesiSelatan); Samarinda (Kalimantan Timur), dan Manokwari(Papua).

Selain asal daerah berbeda4oeda, para santri berasal dari keluarga dengan latar belakang sosial ekonomi yang berbedapula, jika dilihat jenis pekerjaan orang tuanya, seperti PNS, TNI, POLRI, karyawan swasta, petani, dan pedagang.

Menurut Arif Siraj, bahwa santri yang ada di sini pada umumnya berada pada level menegah ke bawah, jika dilihat dari latar belakang sosial ekonominya. Hal ini disebabkan karena memang fasilitas yang tersediadi sini masih sangat terbatas dan sangat sederhana, sehinggabelum dapat menarik minat masyarakat yang tingkat sosial ekonominya menengah ke atas (wawancara,29 Maret 207)

\section{B.Sistim Pembelajaran.}

Seperti telah dijelaskan pada pembahasan yang lalu bahwa Pesantren Al Istiqamah membina dua jenjang pendidikan, yakni Madrasah Tsanawiyah dan Madrasah Aliyah, yang terbagi atas kelas satu sampai kelas enam. Kelas satu sampai kelas tiga adalah tingkat Madrasah Tsanawiyah, sedangkan kelas empat sampai kelas enam adalah tingkat Madrasah Aliyah. 
Kedua jenjang pendidikan menerapkan dua macam kurikulum yakni kurikulum dari Departemen Agama RI, dan kurikulum pesantren, yang sepenuhnya mengadopsi dari pesantren Darussalam Gontor. Penerapan kedua macam kurikulum ini dimaksudkan agar para santri dapat mengikuti ujian nasional, untuk memperoleh ijazah Tsanawiyah dan Aliyah. Disamping para santri juga dapat memperoleh ijazah pesantren.

Kegiatan belajar mengajar dimulai dari pukul 07.30 sampai pukul 14.45 dengan tiga kali istirahat. Kegiatan belajar mengajar ini dilaksanakan secara klasikal dengan menerapkan kedua jenis kurikulum dengan pembagian masing-masing $50 \%$. Sebagai contohberikut ini akan dikemukakan daftar matapelajaran madrasah dan matapelajaran pondok.untuk Kelas IV tingkat Madrasah Aliyah.

\begin{tabular}{|c|l|l|}
\hline No & Mata Pelajaran Madrasah & Mata Pelajaran Pondok \\
\hline 1 & Bahasa Inggeris & English Lesson \\
\hline 2 & Fisika & Mahfudzat \\
\hline 3 & Bahasa Indonesia & Grammar \\
\hline 4 & Aqidah Akhlaq & Ushul Fiqhi \\
\hline 5 & Bahasa Arab & Tafsir Madarisv \\
\hline 6 & Sejarah Kebudayaan Islam & Tarjamah \\
\hline 7 & Matematika & Bidhayah \\
\hline 8 & Pddk.Pancasila/PPKN & Muthalaah \\
\hline 9 & Bioologi & Tarbiyah \\
\hline 10 & Fiqhi & Sharaf \\
\hline 11 & Kimia & Nahwu Wadhi \\
\hline 12 & Ekonomi Koperasi & Insya' \\
\hline 13 & Geografi & Bulughul Maram \\
\hline 14 & Biologi & Imla' \\
\hline 15 & & Tarikh Islam \\
\hline 16 & & Balaghah \\
\hline
\end{tabular}

Antara mata pelajaran madrasah dengan mata pelajaran pondok diajarkan secara bergantian di dalam kelas. Misalnya kalau jam pertama mata pelajaran Biologi (madrasah) yang diajarkan, maka pada jam kedua diganti dengan mata pelajaran Tarbiyah (pondok).

Menurut Amran bahwa setiap mata pelajaran diajarkan hanya satu jam,kemudian diganti lagi mata pelajaran lainnya pada jam berikutnya.Artinya bahwa setiap mata pelajaran hanya diajarkan satu jam pelajaran. Hal ini dilakukan agar tidak menimbulkan 
rasa bosan bagi para santri dalam menerima pelajaran. (Wawancara,29 Maret 2007).

Mengenai pengkajian kitab kuning yang dilaksanakan dalam kelas, diajarkan langsung K.H.MArif Siraj, yang merujuk pada beberapa kitab diantaranya:

Bidayatul Mujtahid wa Nihayatul Mujtahid,karangan Ibnu Rusyd

Bulughul Maram

TafsirMadarisy

Tarbiyatul At Ta'lim

\section{Radikalisme dan PPM-TMI Al Istiqamah}

Beberapa tahun terkhir ini, bangsa Indonesia dikejutkan beberapa peristiwa bom yang bukan sajamerugikan dari segi materi, tapi memakan korban jiwa. Salah satu peristiwa bom yang cukup dahsyat adalah peristiwa bom Bali yang terjadi tahun 2002 yang lalu. Dari peristiwa tersebut berimbas pada lembagapendidikan agamautamanya beberapa pondok pesantren, karena beberapa pelaku pemboman yang tertangkap ditengarai merupakan alumni pesantren.

Sehubungan dengan hal tersebut,akan dicoba menelusuri sejauh mana potensi radikalisme di Pondok Pesantren Moderen Tarbiyatul Muallimin

Islamiyah(PPM-TMI) Al Istiqamah. Untuk itu akan dikemukakan beberapa tanggapan beberapa pengasuh dan beberapa santri mengenai beberapa issu keagamaan yang berkembang dewasa ini ,diantaranya:

\section{Jihad}

Konsep jihad merupakan salah satu ajaran dalam Islam, namun makna jihad ini dipahami para santri, dengan pemahaman yang beragam. Dari 38 orang santri yang menjadi sampel, 3 orang (7,89\%) menyatakan berperang antar agama; 19 orang (50 $\%)$ menyatakan bersungguh-sungguh menjalankan ajaran agama; jawaban lain-lain sebanyak 16 orang $(42,10 \%)$; dan tidak satupun responden yang memahami jihad sebagai bom bunuh diri, maupun membunuh orang yang berlainan agama. Jawaban lain-lain, berjuang sebanyak 11 orang; melawan hawa nafsu sebanyak 5 orang.Untuk jelasnya dapat dilihat pada tabel berikut. 


\begin{tabular}{|c|l|c|c|}
\hline No & Kategori pemahaman & F & $\%$ \\
\hline 1 & Berperang antar agama & 3 & 7,89 \\
\hline 2 & Bersungguh menjalankan ajaran agama & 19 & 50 \\
\hline 3 & Bom bunuh diri & - & - \\
\hline 4 & Membunuh orang yang berlainan agama & - & - \\
\hline 5 & Lain-lain & 16 & 42,10 \\
\hline & J u m l a h & 38 & 100 \\
\hline
\end{tabular}

SumbenData Primer yang diolah

Dari jawaban responden diatas nampak bahwa tidak satupun responden memahami jihad sebagai tindakan bom bunuh diri, ataupun membunuh orang yang berlainan agama. Hal ini sejalan dengan pandangan yang dikemukakan oleh K.H.M Arif Siraj selaku pimpinan pondok,seperti penuturannya sebagai berikut:

Konsep jihad itu adalah salah satu ajaran dalam Islam. Jihad dalam artian yang kita sudah fahami adalah bersungguh-sungguh dalam memperjuangkan sesuatu yang perlu diperjuangkan sesuai dengan konteksnya. Misalnya di tengah-tengah masyarakat terjadi kemiskinan, maka kita secara bersama-sama sesuai dengan kemampuan memerangi atau memberantas kemiskinan tersebut, kemudian Islam diserang orang, terus ada sekelompok orang bangkit melawan kezaliman itu, juga jihad dalam Islam.

\section{Aksi Bom bunuh diri.}

Perilaku bom bunuh diri yang terjadi akhir-akhir ini, khususnya di Indonesia cukup mengagetkan berbagai pihak, terutama karena para pelaku bom bunuh diri tersebut meyakini sebagai jihad dalam mempertahankan agama. Namun di lain pihak, bahkan dari kalangan Islam sendiri menganggap tindakan tersebut merupakan perilaku yang aneh dan hukumnya haram, seperti yang dikemukakan oleh KH. M. Arif Siraj:

Kita dudukkan dulu istilah teroris. Teroris adalah pengacau keamanan. Jadi kalau ada oknum orang Islam melakukan seperti itu, ya Islam juga tidak membenarkan seperti itu. Jihad harus dilakukan dengan memperhatikan prinsipprinsip keseimbangan dalam ajaran Islam. Kalau yang dianggap musuh saat ini menguasai sistem ekonomi umat Islam, maka kewajiban umat Islam adalah berupaya untuk mengeluarkan dari penguasaan tersebut dengan memperbaiki sistem perekonomian Islam. Oleh karena itu, jihad dengan cara bom bunuh diri di tempat-tempat pemukiman, atau keramaian orang yang dianggap musuh ideologi, perekonomian, sosial, kebudayaan, itu hukumnya haram. 
Pendapat tersebut sejalan dengan tanggapan para santri terhadap orang Islam yang melakukan bom bunuh diri, yang pada umumnya menyatakan tidak setuju, bahkan sangat tidak setuju. Untuk jelasnya dapat diuraikan sebagai berikut: 21 orang $(55,26$ $\%)$ menyatakan tidak setuju; 14 orang $(36,84 \%)$ menyatakan sangat tidak setuju. Sedangkan yang menyatakan setuju hanya 3 orang $(7,89 \%)$. Pendapat tersebut sangat bersesuaian dengan penilaiannya terhadap agama Islam. Ustaz Arif mengatakan bahwa agama Islam adalah mhmatan lilalamin.

Demikian pulapenilaian para santri, yang hampir separuh diantaranya atau 18 orang $(47,36 \%)$ yang menilai bahwa agama Islam adalah agama rahmatan lilalamin; 14 orang $(36,84 \%)$ menilai agama dunia akhirat; 4 orang $(10,52 \%)$ menilai agama damai; 2 orang $(5,26 \%)$ menilai agama akhirat saja; dan tidak satupun responden menyatakan agama dunia saja.

\section{Pluralisme Agama}

Suatu kenyataan bahwa di Indonesia terdapat lima agama yang berbeda. Dalam konteks ini terdapat perbedaan sikap di kalangan masyarakat Islam terhadap pluralisme agama atau hubungan antar sesama penganut agama yang berbeda. Pertama, kelompok yang sama sekali tidak mau berhubungan dan cenderung menganggap penganut agama lain sebagai musuh. Kedua, kelompok yang bersikap tidak menolak dan mau melakukan hubungan sosial tetapi dengan batasan tertentu. Ketiga, kelompok yang secara terbukamelakukan hubungan sosial secara wajar.

Dari ketiga kelompok di atas, pesantren Al Istiqamah, termasuk kelompok yang kedua, yaitu melakukan hubungan tapi dengan batasan tertentu, sebagaimana yang dikemukakan oleh K.H.M.Arif Siraj.

\footnotetext{
Keberadaan agama lain saya tetap akui, tapi saya merasa bahwa agama yang saya anut sekarang ini (Islam) itulah yang paling benar mengenai hubungan dengan penganut agama lain, ya kita harus lihat konteksnya dulu, kalau dalam konteks ibadah atau aqidah tidak boleh. Tapi kalau dalam konteks sosial, seperti membersihkan kampung, baru boleh.
}

Pendapat tersebut sejalan dengan sikap para santri yang bersedia melakukan hubungan dengan penganut agama lain. Sikap tersebut dapat dirinci sebagai berikut; dari 38 orang responden, 27 orang $(71 \%)$ menyatakan mau menjalin hubungan dan 
memperlakukan dengan baik, dan 11 orang $(28,94 \%)$ yang menyatakan melakukan hubungan, namun tetap membatasi did. Dan tidak satupun santri yang menyatakan tidak mau menjalin hubungan, bahkan memerangi.

\section{Penegakan Syariat Islam}

Gerakan penegakan Syariat Islam merupakan salah satu wacana yang cukup menonjol pasca reformasi. Wacana ini muncul akibat kekecewaan sebahagian umat Islam atas gagalnya penegakan hokum,dan semakin merajalelanya korupsi yang sampai saat ini tidak bisa diberantas.

Terkait wacana ini, melahirkan sikap beragam dari para santri, ketika dimintai tanggapannya terhadap penerapan Syariat Islam dengan Undang-Undang. Berikut sikap para santri (responden). 14 orang $(36,84 \%)$ menyatakan sangat setuju; 13 orang $(34,26 \%)$ menyatakan setuju; sedangkan yang menyatakan kurang setuju sebanyak 11 orang $(28,94 \%)$. Namun demikian tidak satupun responden yang menyatakan tidak setuju terhadap penerapan syariat Islam. Pendapat para santri tersebut menunjukkan suatu keinginan yang kuat ditegakkannya syariat islam,meskipun mereka pada umumnya masih berusia muda.

Sikap yang sama dikemukakan oleh Arif Siraj,namun dia tidak setuju apabila penegakan syariat digiring padaranah politik.Selanjutnya Arif Siraj mengemukakan sebagai berikut:

\footnotetext{
Penegakan syariat memang perlu, tapi tidak perlu dengan melalui dengan undang-Undang atau Perda, karena disana sangat penuh dengan nuansa politis. Penegakan Syariat Islam harus dimulai dengan penyadaran masyarakat. Dan disinilah dulu saya berbeda pendapat dengan salah satu ormas Islam dalam satu seminar, yang mengatakan bahwa penegakan syariat Islam harus melalui sistim pemerintahan khalifah
} 


\section{KESIMPULAN}

Berdasarkan uraian yang telah dikemukakan di atas, maka dapat ditarik beberapa kesimpulan sebagai berikut.

Tuduhan yang dilontarkan oleh negara-negara Barat terhadap lembagapendidikan Isl am seperti pesantren sebagai tempat pembasisan atau produk teroris atau radikalisme, ternyata tidak terbukti, setidaknya di Pesantern Al Istiqamah. Meskipun kenyataan menunj ukkan bahwa beberapa pelaku bom bunuh diri merupakan alumni pesantren.

Ada dua faktor yang menyebabkan pesantren ini tidak mungkin melahirkan radikalisme yaitu. Pendidikan agama merupakan bagian dari pendidikan nasional, oleh karena itu Pemerintah, dalam hal ini Departemen Agama memiliki kewenangan untuk mengontrol lewat penerapan kurikulumnya. Kedua, kurikulum pesantren yang di terapkan di pesantren Al Istiqamah sepenuhnya mengadopsi dari pesantren Darussalam Gontor, yang dikenal menganut faham yang moderat.

Ada beberapa indikator yang ditunj ukkan pesantren Al Istiqamah tidak berpotensi menganut faham radikalisme diantaranya: Sikap tidak menyukai aksi kekerasan dengan tindakan bom bunuh diri oleh beberapa oknum orang Islam, meskipun dengan alasan jihad. Kemudian mereka mengakui keberadaan penganut agama lain,yang diimplementasikan dengan melakukan hubungan sosial dengan penganut agama lainnya. 
Abd. Kadir R

\section{DAFTARPUSTAKA}

Antoum, Richard,2003, Memahami Fundamentalisme, \rjemahw Muhammad Shadiq, Pustaka Eureka, Surabaya.

Azra, Azyumardi, 1993, Fenomena Fundamentalisme Dalam Zs/am,dalam Ulumul Qur'an No.3 Vol.IV, Jakarta.

From,Erich, 2002, Akar Kekerasan ,Analisis Psikilogis Atas Watak Manusia, Pustaka Pelajar, Jogyakarta.

Jamhari, Jajang Jamroni,2004, Gerakan Salafi Radikal di Indonesia,FT.Raja Grafindo Persada, Jakarta.

Mastuhu,tt, Dinamika Sistem Pendidikan Pesantren, P3M, Jakarta.

Moleong,Lexy, 1989, Metodologi Penelitian Kualitatif, Remaja Karya, Bandung.

Rahim, Husni,2001, Arah Baru Pendidikan Islam di Indonesia, PT.Logos Wacana Ilmu, Jakarta, 